NBER WORKING PAPER SERIES

\title{
EXCHANGE RATE DETERMINATION WITH SYSTEMATIC AND UNSYSTEMATIC POLICY REGIME CHANGES: \\ EVIDENCE FROM THE YEN/DOLLAR RATE
}

\author{
John H. Makin
}

Raymond D. Sauer

Working Paper No. 1406

\author{
NATIONAL BUREAU OF ECONOMIC RESEARCH \\ 1050 Massachusetts Avenue \\ Cambridge, MA 02138 \\ July 1984
}

Support is gratefully acknowledged from: The Center for the Study of Banking and Financial Markets, the Suntory Foundation, National Science Foundation Grant No. SES-8112687 and the National Institute for Research Advancement, Tokyo. The research reported here is part of the NBER's research programs in Financial Markets and Monetary Economics, International Studies and Taxation. Any opinions expressed are those of the authors and not those of the National Bureau of Economic Research. 
NBER Working Paper \#1406

Ju 1 y 1984

\section{Exchange Rate Determination with Systematic and Unsystematic Policy Regime Changes: \\ Evidence From the Yen/Dollar Rate}

\section{ABSTRACT}

This paper presents results of estimating an exchange rate equation in light of theoretical considerations regarding changes in sterilization and intervention policy and tax policy which imply that the coefficients in the equation will not behave as fixed parameters in a given sample period, as standard econometric practice assumes. We compare the results of ordinary least squares and a random coefficients model of the Japanese Yen-U.S. dollar exchange rate during the floating period of July 1973 through June 1982 .

When systematic end of year policy changes affecting Japanese reserves are explicitly modeled, both OLS and the random coefficients model show increased explanatory power. The random coefficients model appears to be superior to OLS however; by allowing the coefficients to vary over time as required by the economic theory discussed above, estimates of the mean response coefficients for the floating period all have the hypothesized sign, and explanatory power is sharply increased.

John H. Makin

American Enterprise Institute 1150 Seventeenth St., N.W. Washington, D.C. 20036 (202) $862-5800$
Raymond D. Sauer

Department of Economics, DK-30 University of Washington

Seattle, WA 98195

(206) 543-5945 


\section{Introduction}

This paper reports significantly improved results fromestimation during the 'f loating' [July 1973 through June 1982] period of a monetary equilibrinm rational expectations (MERE) expression for the yen/do1 lar exchange rate. There are two sources of the improvement over results reported elsewhere in Makin (1981, 1982) and over results witherchange rate equations in general which, as Meese and Rogoff (1983) have demonstrated, have been somewhat disheartening.

The first and most important source of improvement arises from a 110 ance for intervention policy and tax policy regime changes. More recent1y, Branson (1983) has paid attention to the former while Makin (1984) addresses the 1atter. A rational expression for the exchange rate which incorporates intervention and sterilization together with after-tax uncovered interest parity, conditions the impact upon the exchange rate of actua 1 and expected changes in explanatory variables nponthe degreo of intervention and sterilization and on relevant effective marginal tax rates, each of which may vary considerably over time. Obviously this violates the assumption that an exchange rate oquation with fixed coefficients can be estimated over a sample period during which there have been changes in the degree of intervention and sterilization, in effective marginal tax rates or both. One way to deal with the complex non 1 inear response of coefficients to continuous and often simataneons changes over time in intervention/sterilization policy and effective maginal tax rates is to hypothesize that coefficients so impacted behave as random variables withastablemean and finite variance. Suchan approach is employed in this paper. 
The random coefficients assumption will of course be violated if, in addition to a random pattern, there exists some systematic pattern to the policy regime and its impact on coefficients. It is necessary to control for any systematic element of policy regime behavior. In the case of Japan there emerges a large and systematic 'end of year' pattern whereby reserves are allowed to increase sharply in December and to fall by a nearly equal amount in January--almost as if Japan moves onto a quasi-fixed exchange rate regime daring these months. Employing dummy variables to control for this systematic part of Japanese intervention policy not only improves the fit of our exchange rate equation bat, by eliminating significant 'outliers' which violate the random coefficients model assumptions yields results that are fally consistent with the MERE mode1. In short, the second source of our improved results, controlling for systematic Japanese intervention behavior at year end, is sufficient to preclade rejection of the hypothesis that nonsystematic intervention/sterilization and tax policy regime changes in both the United States and Japan require that a random coefficients model be employed to test hypotheses embedded in rational models of exchange rate determination.

Before proceeding to specifics, it is worthwile to place this investigation within the context of two non-contradictorybut different approaches to improving the fit of exchange rate equations that have emerged over the past decade from extensive and often innovative empirical investigations of exchange rate behavior. ${ }^{1}$ One approach, whereby assets denominated in different currencies are viewed as imperfect substitutes, points to inclusion in exchange rate equations of 'left out variables' needed to account for a systematic difference between the forward rate and the expected spot rate. The imperfect substitutes hypothesis suggests 
significant deviations from uncovered interest parity which are consistent with eithor foreign exchange market inefficiency (generally rejected as a prior hypothesis) or time varying risk preminms. In turn, since the existence of time varying risk preminms is consistent with imperfect substitutability between assets denominated in different currencies, it thereby--given risk aversion--implies a significant effect of sterilized intervention on exchange rates. ${ }^{2}$

The second approach, followed here, attributes less significance to deviations from uncovered interest parity as a source of poor exchange rate equation fits and attribates more significance to policy regime changes. The operational result of the second approach is to try and improve the fit of exchange rate equations by a 110 ing for both systematic and random effects of policy regime changes. It is worth noting that empirical tests under both approaches may be biased by failing to specify uncovered interest parity in after-tax terms. ${ }^{3}$ We avoid suchbias by employing an after-tax expression for uncovered interest parity. Onceestimated, our random coefficients mode 1 which includes as explanatory variables on 1 y measures of relative excess money supplies in Japan and the Onited States performs quite we 11 and displays no gross symptoms of left out variables.

The remainder of the paper is arranged as follows. Section 2 briefly 1ays out an intervention/sterilization and tax policy regime augmented version of the MERE mode1, first developed for a simple floating regime by Bilson (1979) and later extended, first to an intervention/sterilization regime model by Makin (1981) and then extended to include tax regimes by Makin (1984). Section 3 describes briefly the random coefficients procedure employed to estimate the mode1. Section 4 presents results of estimating the mode 1 for the yen-do11arexchangeratewithmonth1y data 
running from July, 1983 through Jane, 1982. Some concluding comments are presented in Section 5 .

\section{Rrchengo Rete Mode1}

Here a rational expression for the equilibrium exchange rate is derived froma simplestracture including money demand equations in two contries, parchasing power parity (which can be expanded to al 10 for 'roal' exchange rate changes) and an after-tax covered interest parity equation. We also al 1 ow for official exchange market intervention and the presence or absence of sterilization of effects of intervention on the monetary base.

The solution to the two country model after some algebra and iterative substitution is a parametized expression for the exchange rate in terms of: relative (exogenons portions of) money supplies, relative real output, and 'rea1' exchange rate changes. Parameters which determine the exchange rate in terms of current actual and expected future values of these variables include the income and interest elasticities of money demand in each country, tax rates on interest income, and foreign exchange gains and losses in each country and--of particular significance for the investigation proposed here--the degree of sterilization and intervention in each country.

A basic solution employing the procedure just ont 1 ined, following Makin (1981, 1983) is obtained as follows. Based on log linear money demand oquations in countries ' 1 ' and ' 2, ' purchasing power parity and deviations therefrom ('real' exchange rate changes) an expression for the $10 g$ of the spot exchange rate may be written as

$$
s_{t}(1-0)=\underline{d e} t-a \underline{y}_{t}+d z_{t}+b\left(i_{1}-i_{2}\right)+\underline{n}_{t}
$$


where:

$$
\begin{aligned}
& { }^{t}=10 g \text { of spot exchange rate (currency } 1 \text { prico of carrency } \\
& \text { 2). } \\
& \text { de } t \quad=10 g \text { of exogenous (not tied to sterilization) portion of } \\
& \text { of monetary base in conntry } 1 \text { less } 10 \mathrm{~g} \text { of exogenous } \\
& \text { portion of monetary base in country } 2 \text {. } \\
& Y_{t} \quad=108 \text { of real income in conntry } 1 \text { less } 10 \mathrm{~g} \text { of real income } \\
& \text { in country } 2 \text {. } \\
& \text { z = vector of disturbances which systematicaliy cause } \\
& \text { deviations from purchasing power parity. } \\
& i_{h}(h=1,2)=\text { the nominal interest rate in conntry } h \text {. } \\
& \text { n } \quad=\text { disturbance term in money demand equation for conntry } 1 \\
& \text { less same term for country } 2 \text {. } \\
& \text { a = income elasticity of money demand in country } 1 \text { (set equal } \\
& \text { to that in country 2). } \\
& \text { b = interest elasticity of money demand in countries } 1 \text { and } 2 . \\
& \text { (Note: ' } a \text { ' and ' } b \text { ' can be allowed to differ across } \\
& \text { countries.) } \\
& 0<0 \quad=a \text { term capturing sterilization and intervention behavior } \\
& \text { in conntries } 1 \text { and } 2 \text {. }(\phi=0 \text { with free floating and no } \\
& \text { intervention in foreign exchange markets. See Appendix } \\
& \text { for ful1 derivation.) }
\end{aligned}
$$

An expression for the difference between nomina 1 interest rates can be derived from after tax covered interest parity: ${ }^{4}$

$$
i_{1}-i_{2}=\beta\left(f_{t}-s_{t}\right)
$$

where

$$
\begin{aligned}
& \ln (1+i) \quad i \text { for sma } 11 i \\
& f_{t}=\log \text { of the forward rate at time } t . \\
& s_{t}=\log \text { of the spot rate at time } t . \\
& \beta=\quad-0 \text { as } \tau_{k}-\tau
\end{aligned}
$$


and

$$
\begin{aligned}
& \tau=\text { marginal tax rate on interest income in conntry } 1 . \\
& \tau_{k}=\text { marginal tax rate on exchange gains in country } 1 .
\end{aligned}
$$

Equation (2) says simply that if the tax on exchange gains $\tau_{k}$ is less than the tax on interest income then the interest differential between countries 1 and 2 willexceed the exchange gain or loss. Obviously if $\tau_{k}=\tau$, the considerations wash out and bofore and after-tax covered interest parity conditions are identical.

In most cases, the tax on exchange gains is below the income tax rate. See Peat, Marwick, Mitche11 and Co. (1979) for a full discussion. For D.S. corporations $\tau_{k}=0.30$ for positions he 1 d more than 12 months whi 1 e $\tau=$ 0.48 so that $\beta=1.35$. In practice actua 1 marginal income tax rates for corporations as we 11 as households may be lower and may vary considerably over time. (See Tanzi (1982) and Estrel1a and Fuhrer (1983)).

Traditiona11y, deviations from covered interest parity expressed by equation (2) have been attributed to political risk and/or portfolio balance considerations. 5 Some current studies such as Ito (1983) have found results for Japan-U.S. which are genera11y consistent with $\beta=1.0$ during the 1975-80 period and consistent with $\beta<1.0$ thereafter. $\beta<1.0$ is consistent with $\tau>\tau_{k}$, contrary to expectations based on the U.S. tax code. In contrast, Batz (1983) reports results for the United States and seven industrial countries which suggest $\beta>1.0$ over the short run which is another odd result, since usually short run exchange gains are taxed at the same rate as interest income. Katz's results may bedue partiy to measurement error since he in effect uses expected inflation differentials to measure expected depreciation--thereby hypothesizing satisfaction of parchasing power parity-and then estimates what amounts to an uncovered 
interest parity equation. In sum, whilo empirical evidence on $\beta$ is inconclusive at this stage, some allowance for possiblo changes over time is prudent.

If assets denominated in currencies 1 and 2 are perfoct substitutes, no risk premium separates the $10 \mathrm{~g}$ of the forward rate, $f_{t}$, from the $10 \mathrm{~g}$ of the expocted spot rate-at time $t$ for time $t+1, t^{s^{e}} t+1$. Therefore:

$$
f_{t}=t^{s}{ }_{t+1}
$$

Substituting from (3) into (2) gives:

$$
i_{1}-i_{2}=\beta\left[t_{t+1}{ }^{e}-s_{t}\right] \text {. }
$$

Substituting from (4) into (1) for $i_{1}-i_{2}$ and rearranging terms gives:

$$
s_{t}=\quad t^{s^{e}}{ }_{t+1}+\quad\left(\underline{d e}_{t}-a \underline{y}_{t}+d z_{t}+u_{t}\right)
$$

Substituting iteratively to solve for $t^{s}{ }_{t+1}^{e q u a t i o n ~(5) ~ b e c o m e s: ~}$

where

Equation (6) describes the spot exchange rate as being determined--in a manner set by money demand parameters, sterilization and intervention 
policy and tax rates--by current actual and expected fatare values of the set of exogenons variables, de, $I$, and z defined above.

A primary conclusion from the discassion of exchange rate determination summarized in equation (6) is the implied offect on the exchange rate of current and prospective policies regarding intervention, sterilization and tax rates appliod to interest earnings and to foreign exchange gains and losses. Announcement of expected future changes in such policies will change the carrentequilibrinm spot rate in the forwardlooking foreign exchange market even if carrent and prospective values of exogenous variables remain unchanged.

Since takes on a larger negative value as intervention is stepped up to smooth exchange rates, the result of more aggressive intervention is to reduce exchange rate changes in response to given changes in actal or expected values of relative excess money supplies or other disturbances. Considerable variation over a given sample period in the degree of exchange market intervention will resultin a por fit of a fixed-coefficient equation over that sample period. The same vill hold true for changes in effective marginal tax rates over a samplo period. A possible remedy is to control for any systematic changes in intervention policy or tax rates and to attempt to capture nnsystematic changes with a random coefficients mode 1

\section{Methodology}

Given that our focus is on incorporating the effects of systematic and nnsystematic policy changes on the coofficients in an exchange rate equation, wo adopt a simple version of (6), abstracting from variations in a risk preminm, specification of disturbances cansing systematic deviations from purchasing porer parity, and representations of expected futare 
erogenous variables. With these qualifications, we proced to eramine the following eqation (a11 variables in $10 \mathrm{~g}$ first differences):

$$
s_{t}=a_{0}+a_{1} J R_{t}+a_{2} J P_{t}+a_{3} U S R_{t}+a_{4} U S P_{t}
$$

$$
\text { (0) }(+) \quad(-) \quad(-) \quad(+)
$$

or $\quad s_{t}=a x_{t}$

where

$$
a=\left(a_{0}, a_{1}, a_{2}, a_{3}, a_{4}\right)^{\prime}
$$

$x_{t}=\left(1, J R_{t}, J P_{t}, U S R_{t}, U S P_{t}\right)$

$s_{t}=$ yen per dollar; monthly average of daily data.

JR(USR) $10 \mathrm{~g}$ of domestic (exogenous) portion of the monetary base for Japan (United States): measured by 'monetary authority reserve money' ( 1 ine 14) in IMF International Financial Statistics.

JP(USP)=1 og of industrial production for Japan (United States): 1ine $66 \mathrm{c}$ of IMF International Financial Statistics.

Equation (7) implies a number of maintained hypotheses, including:

(a) stable money demand functions: (b) after-tax covered interest parity with stable effective marginal tax rates: (c) stable intervention and sterilization policies in both countries; (d) current growth rates of explanatory variables as prories for both carrent and expected futare growth rates: and (e) the 'real' yen/dollar rate follows a random walk. Violations of (a), (b) [stable effective marginal tax rates] and (c) can be entertained ander the random coefficients approacemployed belor to ostimate (7). Simple extrapolitive models (AR-1, with seasonal terms for Japanese reserves) adequately mode 1 growth rates for explanatory variables, so current growth rates capture both carrent actual and expected fature growth rates. Eramination of the real yen/dollar rate behavior during the Jaly, 1973 - Jane, 1982 sample period revoals that residuals from its $10 \mathrm{~g}$ 
first differences are 'white noise' $Q(24)=23.4$ which is consistent ith (a).

Remaining questions regarding maintained hypotheses center on the assumption of perfect substitutability between yen and dollar assets (satisfaction of covered after tax interest parity.) Evidence on perfect substitutability is mixed with Hendersonet a 1. (1984) reporting that perfect substitatability between yen and dollar assets cannot be rejected nnder rational expectations while Hansen and Hodrick (1983) are nnable to reject the hypothesis of a time-varying risk preminmfor the yen-dol 1 ar rate.

In effect, our estimates of exchange rate equations reported below a 1 low for time-varying parameters while imposing after-tax covered interest parity and employing only the simplest measures of explanatory variables. 6

In most econometric applications, the coefficients are estimated as constants throughout the time period being analyzed. This approach is like1y to be inappropriate when applied to an equation such as (7), where the coefficients are subject to the several sources of variation just discassed. Hildreth and Houck (1968) have outlined a procedure whereby consistent estimators can be obtained for a model which allows the coefficients to vary over time. The estimated coefficients are interpreted as the 'mean response' coefficients. The statistical model is sumarized by:

$$
\begin{aligned}
s_{t} & =x_{t k} a_{t k}=x_{t k}\left(\alpha_{k}+v_{t k}\right) \\
& =x_{t k} \alpha_{k}+e_{t} \\
e_{t} & =x_{t k} v_{t k}
\end{aligned}
$$


where $\quad E\left(v_{t k}\right)=0$

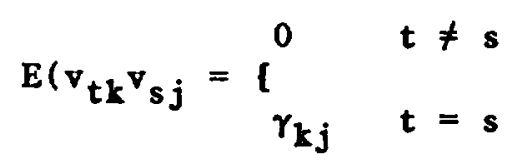

thes

$$
E\left(a_{t k}\right)=a_{k}
$$

Consistent estimators for $a_{k}$ can be obtained with a generalized least squares procedure using an estimated covariance matrix for e:

$$
\theta=(\dot{M} \cdot \dot{M})^{-1} \dot{M} \cdot \mathbf{v}
$$

where $\dot{M}$ is a matrix containing the squared elements of $\left(I-X\left(X^{\prime} X\right)^{-1} X^{\prime}\right)$ and $\dot{c}$ contains the squared residals from an ordinary least squares regression on (7). The GLS vector containing the estimated mean response coefficients is obtained from 7

$$
a=\left(X^{\prime} \theta^{-1} X\right)^{-1} X^{\prime} \theta^{-1} \mathbf{Y}
$$

\section{Bstination Results}

The oLS and random coefficients results from regressions on equation (7) appear in Table 1. The oLS equation gie1ds virtualy no explanatory power as $R^{2}=.01$. Applying the random coefficients procedare ont 1 ined above provides no dramatic improvement--indeed the signs of the $0 . S$. variables are the reverse of those implied by theory. 
TARB 1

TEY/DOLLAR EXCHANGB RATB: JULT 1973 - JUNB $1982 *$

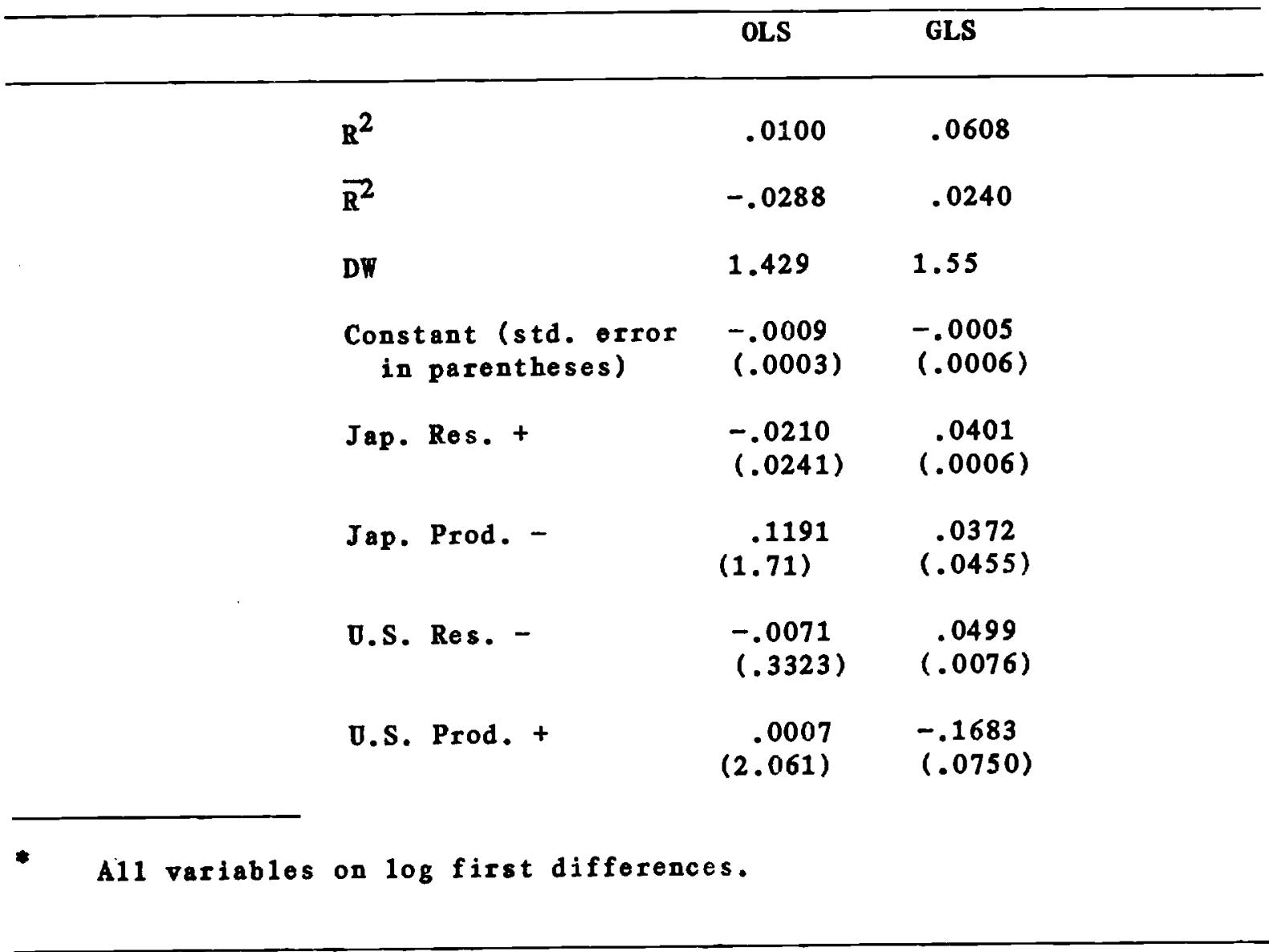

However, a close look at the data reveals that (7) is not an entirely correct specification of the exchange rate equation. Japanese reserves systematicaliy rise sharply in December, and fall by roughly the same magnitude the following January. The magnitude of these end of year reservechanges averages roughly five times that of the wonthlychanges throughout the remainder of the year.

Systematic policy changes of this nature can be handled using oLs and dummy variables for the months in which this occurs. We thus redefine (7) as

$$
s_{t}=a_{0}+a_{1} J R_{t}+a_{2} J P_{t}+a_{3} \delta S R_{t}+a_{4} J S P\left(t+a_{5} J R D_{t}+a_{6} J R J_{t}\right.
$$


where JRD takes the value of $J_{R_{t}}$ if the month is Decomber and is zero otherwise. JRJ is similarly defined.

Failure to account for this policy shift is likely to bias the estimate of $a_{1}$ downward in a regression on (7), as the dramatic increase (decrease) in Japanese reserves in December (January) is 1 ikely to be heavily disconnted in foreign exchange markets. We thas expect to see an increase in the estimated coefficient for $\alpha_{1}$, and hypothesize that the signs of $a_{5}$ and $a_{6}$ are negative in (12).

The econometric results from estimation of (12) are presented in Table 2. The OLS equation shows some improvement over its counterpart, a 1 though again, only the estimated coefficient on Japanese reserves changes exceeds its standard error. In addition, the signs of the estimated coefficients for Japanese Production and U.S. Reserves are the opposite of what the theory predicts.

However, as hypothesized, incorporating systematic policy changes through the inclusion of the December and Janary Reserve dummies results in an increase in the estimated coefficient for Japanese Reserves, with negative coefficients estimated for the dummy variables.

The application of the random coefficients model yields improvement in each and every statistical category. Al 1 estimated coefficients are of the hypothesized sign, and the standarderror of each coefficient is redaced relative to its conterpart in Table 1. (The standarderror of the mean response coefficient for Japanese Reserve changes is reduced relative to the estimated coefficient by a factor of four). R-squared rises to.4039 and the Darbin-Watson statistic a 1 so improves to 1.8606 . 
TABIB 2

TEY-DOLLAR RATE WITH DUOURS POE STSTMUTIC

INTERVENTION: JULT, 1973 - JUNB, 1982*

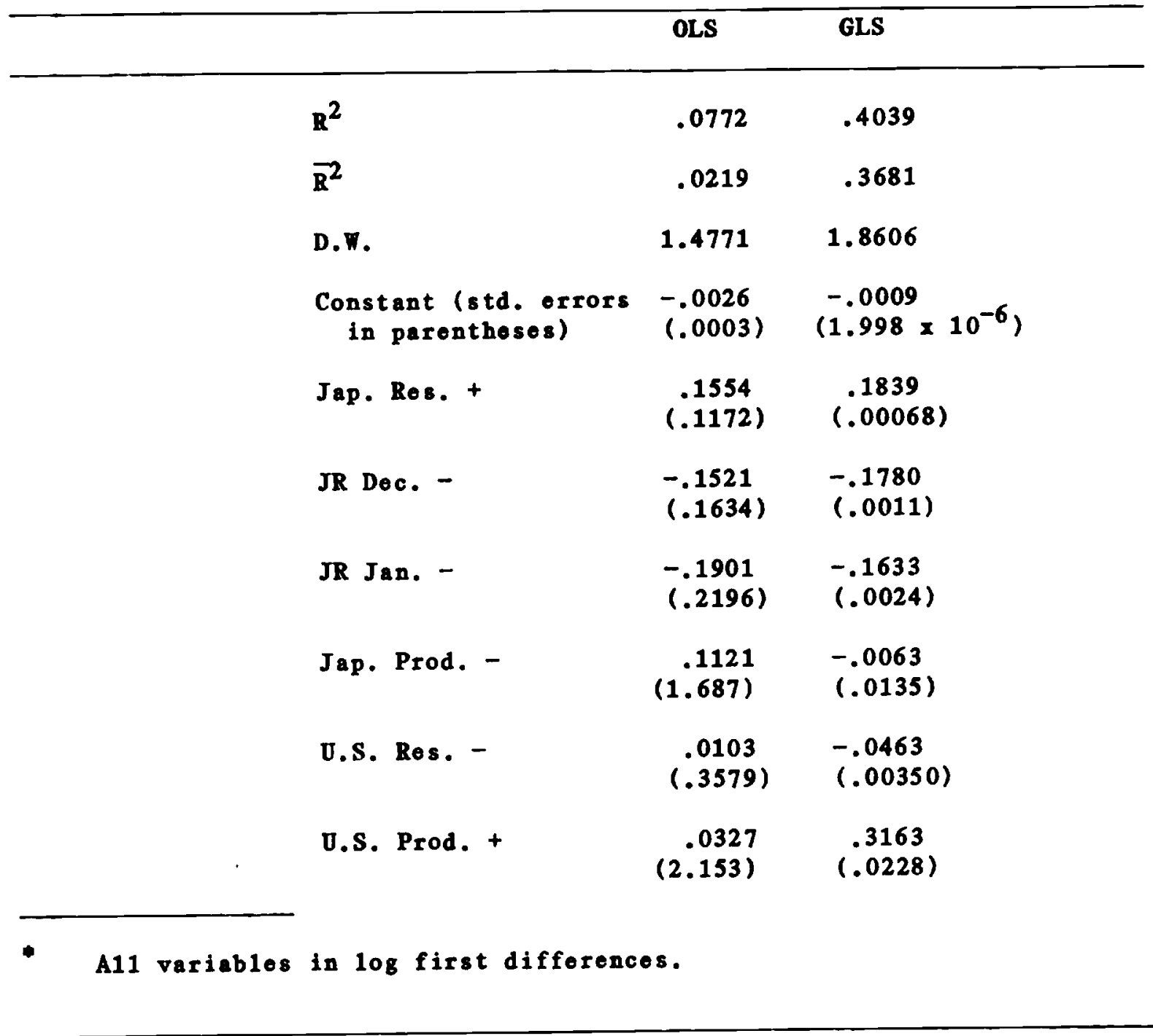

In both versions, the effect of the dumbies is to reduce sharply the impact of Japanese Reservo Changos in December and January. The degree to which such reserve changes are reduced in the random coofficients version is rovghiy the samo in bothmonths, leaving sma11, positive offect of Japanese Reserve Changes on the exchange rate during these months. 
Overa11, onr results are consistent with the hypothesis that regime changes and/or instability of money demand equations acoont for a significant portion of the poor fit of yen/dollar equations during the 'floating' poriod. 8

\section{Sumary}

This paper presents results of estimating an exchange rate equation in light of theoretical considerations regarding changes in sterilization and intervention policy and tax policy which imply that the coefficients in the equation will not behave as fired parameters in a given sample period, as standard econometric practice assumes. We compare the results of ordinary least squares and a random coefficients model of the Japanese yen-D.s. dollar exchange rate during the 'floating' period of Jn1y 1973 through Jnne 1982.

When systematic end of year policy changes affecting Japanese reserves are explicit 1 y mode1ed, both OLS and the random coefficients mode 1 show increased explanatory power. The random coefficients model appoars to be superior to ols however: by allowing the coefficients to vary over time as required by the economic theory discussed above, estimates of the mean response coefficients for the floating period a 11 have the hypothesized sign, and explanatory power is sharply increased. These improved results strongly suggest that a random coofficients model is a useful technique for modeling exchange rate determination during quasi floating regimes where responses of exchange rates to changes in relative excess money supplies are likely to vary over time. 


\section{Poomings}

1. For an excel1ent 'review of the troops' see the volumes edited by Frenke1 (1983) and Hawkins, Levich and Wiblborg (1982).

2. See Henderson et $\underline{\text { 1. }}$. (1984) for a discasion of evidence on imperfect substitutability and Hodrick and Srivastava (1984) for a state-of-theart discussion of time varying risk preminms. On efficiency and related hypotheses, see also Hansen and Hodrick (1980).

3. Makin (1984) demonstrates that failure to specify arbitrage equilibria in after-tax terms may bias investigations of deviations from nncovered interest parity toward rejection of the hypothesis that assets denominated in different currencies are perfect subsitutes.

4. If country 2 has an asymmetric tax treatment of exchange gains and interest income then equation (1) may hold without satisfying covered interest parity for conntry 2. This case is examined for Canada and the Dnited States by Levi (1977). Such asymmetry raises the possibility of simultaneous two way capital flows and also raises an interesting question of how long ran equilibriam is achieved. For now we assume that conntries 1 and 2 have symmetric tax systems so that equation (1) describes covered interest parity for both or, alternatively that conntry 1 is so large relative to conntry 2 that it dominates markets sufficiently to preclude significant deviations from equation (1).

5. See Aliber (1973, 1975) and Frenkel and Levich (1975).

6. Lagged independent variables were tried but added nothing to the explanatory power of contemporaneous independent variables alone. 
7. Equation (11) bypasses the question of the ostimated variances of the random coefficients. This is necessary due to the inclosion of dumy variables in the model, which causes the matrix required for estimation of the variance of the coefficients to be singular. This precludes the possibility of providing estimates of the $v_{t k}$ and hence a time path of the random coefficients.

8. Hodrick and Srivastava (1984) and Papel1 (1984) report evidence of regime changes but also find evidence of systematic deviations from uncovered interest parity. 


\section{APPBNIX \\ HONET SUPPLI: STRPILIZATION AND INIRRVETION}

Money supply is represented by a log linear money 'production function' which determines money supply in terms of domestic and foreign assets of the central bank. For country 1, let:

$$
M_{1} s=D_{1}^{1} x_{1}{ }^{2}
$$

where: $\mathrm{M}_{1}^{\mathrm{s}}=$ money supp $1 \mathrm{y}$.

$D_{1}=$ domestic assets of contral bank in conntry '1.'

$x_{1}=$ foreign exchange reserves of central bank in country ' 1 .'

$j_{1}=$ elasticity of money supply with respect to $D_{1}$.

$j_{2}=$ elasticity of money supply with respect to $x_{1}$.

In logs (A.1) becomes:

(A.2) $\quad m_{1}=j_{1} d_{1}+j_{2} x_{1} \cdot$

Sterilization links d negatively to reserves

(A.3)

$$
d_{1}=d_{1}-\left(1-s t_{1}\right) x_{1}
$$

where: $d e_{1}=10 \mathrm{~g}$ of antonomous portion of domestic assets of central bank in country 1 .

$$
\begin{aligned}
\text { st }_{1}= & \text { sterilization coefficient in country } 1 \text { [st }_{1}=0 \text { implies } \\
& \text { full sterilization; st } t_{1}=1.0 \text { implies } \\
& \text { zero sterilization and } \left.d_{1}=d_{e}\right] .
\end{aligned}
$$

Intervention links reserves to the exchange rate where: 
(A.4)

$$
\mathbf{x}_{1}=-\gamma_{1} s
$$

$\gamma_{1}$ measures the elasticity of official reserves with respect to the exchange rate, s. The faster currency 1 deprociates (a rise in s) the faster conntry 1 reserves are lost (and the faster 'foroign' reserves rise). If analogous expressions apply for country 2 , then $\underline{m}_{t}$, the relative money supply term for countries 1 and 2 , can be written as:

$$
\underline{m}_{t}=\underline{d e}_{t}+s_{t}
$$

where:

$$
\begin{aligned}
& \stackrel{d e}{t}=j_{1} d e_{1}-j_{1}^{*} d e_{2} \\
& (\leq 0) \quad\left[-\gamma_{1}\left(j_{2}-j_{1}\left(1-s t_{1}\right)\right)-\gamma_{2}\left(j_{2}^{*}-j_{1}^{*}\left(1-s t_{2}\right)\right)\right] .
\end{aligned}
$$

If intervention dominates sterilization so that corrency depreciation lowers $x_{1}$ and raises $x_{2}$ then is nnambiguously negative. If sterilization eradicates intervention's affect on the monetary base $=0$. In this case $\underline{m}_{t}=\underline{d e}_{t}$ and there is no need to take account of either intervention or sterilization in modeling the money supply. The important thing about (A.5) from the standpoint of estimation is the fact that it 1 inks to ' ${ }^{\prime}$ '. the value of all reduced-forms describing the impact upon the exchange rate of exogenous variables. And ' $\theta$ ' in turndepends npon intervention and sterilization policy parameters $\gamma_{i}$ and $s t_{i}(i=1,2)$ which are 1 ikely to change over time. 


\section{PEPRRPMCES}

A 1 iber, R.z. (1973). 'The Interest Parity Theorem: A Reinterpretation,' Journal of Political Economy (November/December 1973): 1451-59.

(1975). 'Exchange Risk, Politica 1 Risk and Investor Demand for Externa 1 Currency Deposits,' Journa 1 of Money, Credit and Banking (May. 1975): $161-80$.

Bilson, John F.o. (1979). 'Recent Developments in Monetary Mode1s of Exchange Rate Determination,' IMF Staff Papers (June, 1979): 201-23.

Branson, W.H. (1983). 'A Mode1 of Exchange-Rate Determination With Policy Reaction: Evidence From Month1y Data.' NBER Working Paper, No. 1135 (June, 1983).

Estre 11 a, A. and J.C. Fahrer (1983). 'Average Marginal Tar Rates for U.S. Horsehold Interest and Dividend Income 1954-1980,' NBER Working Paper No. 1201, September 1983.

Frenke 1,J.A. and R.M. Levich (1975). 'Covered Interest Arbitrage: Onexploited Profits?' Journal of Political Economy (Apri1, 1975): 325-38.

Frenke 1, J.A., ed. (1983). Exchange Rates and Internationa 1 Macroeconomics, University of Chicago Press, Chicago and London.

Hansen, L.P. and R.J. Hodrick (1980). 'Forward Exchange Rates as Optima 1 Predictors of Future Spot Rates: An Econometric Analysis, Jonrnal of Political Economy (October): 829-53.

(1984). 'An Investigation of Risk and Return in Forward Foreign Erchange,' Jonrnal of International Moner and Finance (Apri1, 1984).

Hawkins, R.G., R.M. Levich and C.G. Wihlborg, eds. (1983). The Internationalization of Financial Markets and Nationa 1 Economic Policy. JAI Press, Greenwich, Conn.

Henderson, D., D. Danker, R. Haas, S. Symansky and R. Tryon (1984). 'Sma 11 Empirical Mode1s of Erchange Market Intervention: A Revier of the Literature,' Board of Governors of the Federal Reserve System, Washington, D.C. (January).

Hildreth, C. and J.P. Houck (1968). 'Some Estimators for a Linear Mode1 with Random Coofficients,' Jonrna 1 of the American Statistical Association 63: 584-95.

Hodrick, R.J. and S. Srivastava (1984). 'An Investigation of Risk and Return in Forward Foreign Exchange, Journa 1 of Internationa 1 Money and Finance (Apri1, 1984). 
Ito, T. (1983). 'Capital Controls and Covered Interest Parity,' NBER Working Paper, No. 1187 (August).

Katz, M. (1983). The Impact of Taxation on Internationa 1 Capital Flows-Some Empirical Estimations,' International Monetary Fund DM/83/81, November 30, 1983.

Levi, M.D. (1977). 'Taxation and 'Abnorma 1' International Capital F1ows,' Journal of Political Economy (June): 635-46.

Makin, J.H. (1981). 'Exchange Rate Behavior Under Ful1 Monetary Equilibrinm: An Empirical Analysis,' NBER Working Paper, No. 647 (March).

(1982). 'Determinants of the Yen-Do11ar Exchange Rate: The Course of the United States and Japanese Policies' in Policy and Trade Issues of the Japanese Economy, ed. K. Yamamura, University of Tashington Press, Seatt1e.

(1983). 'Techniques and Success in Forecasting Exchango Rates: Should It Be Done? Does It Matter: The Long and Short of it, Research in Internationa 1 Business and Finance, Vo1. 3, pp. 149-80, JAI Press, Greenwich, Conn.

- (1984). 'Exchango Rates and Taxes,' NBER Working Paper, No. 1350 (May).

Meese, R. and K. Rogoff (1983). 'Empirical Exchange Rate Models of the Seventies: Are Any Fit to Survive?' Jonrnal of International Economics 14: 3-24.

Pape11, D.H. (1984). 'Monetarist Monetary Policy, Exchange Risk and Exchange Rate Variability,' NBER Working Paper, No. 1306 (March, 1984).

Peat, Marwick, Mitche 11 and Co. (1979). Tax Treatment of Exchange Gains and Losses in Selected Conntries. Peat, Marvick, Mitche 11 and Co.. Paris.

Tanzi, V. (1982). Time Series on Weighted Ayerage Tax on Interest Income 1929-1978, unpub1ished, International hionetary Fund. 